\title{
PENINGKATAN HASIL BELAJAR MATEMATIKA DENGAN MEDIA BUNGKUS BATANG KOREK API PADA SISWA KELAS I SD NEGERI NGIJON 2 TAHUN AJARAN 2017 / 2018
}

\author{
SRI HARYANTI \\ SD Negeri Ngijon 2 \\ Email : haryanti.sh70@gmail.com
}

\begin{abstract}
ABSTRAK
Penelitian ini bertujuan untuk meningkatkan hasil belajar matematika dengan media bungkus batang korek api pada siswa kelas I SD Negeri Ngijon 2 Tahun. Penelitian dilakukan menggunakan pendekatan Penelitian Tindakan Kelas (PTK) oleh peneliti yang merupakan pengampu guru kelas 1. Subyek penelitian adalah siswa kelas 1 SD Negeri Ngijon 2 yang berjumlah 16 siswa. Kegiatan penelitian ini dibagi dalam 2 siklus yaitu siklus yang terdiri dari siklus pertemuan I dan II dengan rancangan tindakan meliputi penyusunan rencana tindakan, pelaksanaan tindakan, observasi terhadap pelaksanaan tindakan dan refleksi. Instrumen yang digunakan meliputi lembar tes observasi. Analisis deskriptif kualitatif dilakukan dengan menghitung nilai tes dan analisis data observasi, hasil penelitian menunjukkan adanya peningkatan hasil belajar dari pra siklus rata-rata 68 meningkat di siklus I menjadi 72,5 setelah dilakukan tindakan siklus I pertemuan II menjadi 74,6 dan meningkat menjadi siklus II pertemuan I nilai rata-rata menjadi 74,68 karena belum mencapai KKM dilakukan tindakan siklus II pertemuan II meningkat menjadi 82,81.
\end{abstract}

Kata kunci : puluhan, satuan, media

\section{PENDAHULUAN}

Pendidikan memiliki peranan yang sangat penting bagi kehidupan manusia. Pendidikan dapat mempengaruhi perkembangan manusia dalam seluruh aspek kehidupannya. Pendidikan di sekolah dasar merupakan salah satu faktor penentu perkembangan manusia. Pendidikan matematika merupakan salah satu muatan pelajaran pada Kurikulum 2013.

Muatan Matematika kelas 1 merupakan dasar atau pondasi yang sangat penting sebagai dasar untuk berhitung. Konsep dasar yang diberikan pada muatan matematika adalah konsep berhitung menggunakan media. Diharapkan guru sebagai pelaku utama dalam pendidikan mampu mengembangkan kreativitasnya dalam mengajar terutama memanfaatkan media pembelajaran.

Hasil pengamatan selama pembelajaran semester I, nilai ulangan harian matematika masih rendah, belum memenuhi KKM yang ditetapkan yaitu 75 . Nilai rata-rata ulangan matematika materi nilai tempat puluhan dan satuan yaitu 68. Siswa yang tuntas 4 orang dan yang belum tuntas 12 . Berdasarkan data dari 16 anak tersebut terlihat $25 \%$ siswa sudah mencapai KKM dan $75 \%$ belum mencapai KKM. Proses pembelajaran matematika yang ada masih monoton, belum menggunakan media. Siswa terlihat tidak bersemangat ketika mengerjakan soal matematika, kurang aktif dalam pembelajaran dan hasil belajar yang masih rendah.

Permasalahan tersebut harus segera diatasi untuk meningkatkan hasil belajar siswa. Oleh karena itu peneliti menggunakan salah satu cara yaitu menggunakan media berupa bungkus batang korek api. Diharapkan siswa mampu aktif, kreatif dalam proses pembelajaran matematika sehingga pembelajaran akan bermakna dan hasil belajar siswa meningkat.

Pembelajaran matematika dalam materi puluhan dan satuan seharunya memberikan konsep tentang puluhan dan satuan yang tepat kepada siswa. Guru mengajarnya kurang maksimal karena belum menggunakan media. Tingkat keberhasilan belajar siswa masih rendah. Sehingga peneliti memilih media pembelajaran yaitu bungkus batang korek api dalam materi nilai tampat puluhan dan satuan. 
Penggunaan media dalam pembelajaran sangat penting untuk memaksimalkan tujuan pembelajaran yang dirancang oleh guru. Media pembelajaran merupakan suatu perantara yang digunakan untuk menyampaikan informasi dengan tujuan dapat memberikan rangsangan kepada siswa untuk belajar. Sebagaimana penjelasan Smaldino, et.al (2011) media diartikan sebagai segala sesuatu yang merujuk pada penyampaian informasi dan pesan antara sebuah sumber dan sebuah penerima sebagai wujud dari sarana komunikasi. Terdapat klasifikasi media menurut Degeng (1989), yaitu visual, audio, dan audio visual. Pemakaian media pembelajaran tersebut telah memberikan pengaruh kepada siswa. Kemasan media pembelajaran yang baik dapat membangkitkan semangat siswa untuk belajar sehingga memperoleh hasil belajar yang maksimal. Selain itu, media juga membawa pengaruh terhadap psikologis (batin, perasaan, sikap, dan karakter) siswa.

\section{METODE PENELITIAN}

Penelitian ini adalah Penelitian Tindakan kelas yaitu penelitian yang dilakukan oleh guru di kelas dengan penekanan pada penyempurnaan / peningkatan praktek dan proses dalam pembelajaran. Penelitian ini menggunakan model penelitian Kemmis dan Mc Taggart. Menurut Suharsimi Arikunto ( 2015 : 42 ) model penelitian Kemmis dan MC Taggart terdiri dari empat komponen yang menunjukkan langkah perencanaan, tindakan, pengamatan dan refleksi. Subjek Penelitian ini adalah siswa SD Negeri Ngijon 2 Moyudan Sleman Yogyakarta berjumlah 16 Siswa. Waktu penelitian sesuai dengan jadwal mata pelajaran di kelas 1 SD Negeri Ngijon 2 sebagai berikut : Senin, 5 Maret 2018 sampai dengan 12 Maret 2018. Jenis data yang dikumpulkan dalam penelitian ini adalah hasil tes evaluasi (data kuantitatif) dan data dari hasil observasi.

\section{HASIL DAN PEMBAHASAN}

Hasil penelitian ini berisi uraian proses dari pra siklus, menjelaskan hasil belajar siswa sebelum diberikan tindakan awal belum menggunakan media, dengan hasil belajar rendah, siswa mengalami kesulitan belajar matematika terutama dalam materi puluhan dan satuan. Pembelajaran hasilnya belum memenuhi KKM dari 16 siswa nilai yang tuntas hanya $25 \%$ atau rata - rata 68.

\section{Siklus 1 pertemuan 1}

Pada kegiatan penelitian yang pertama ini, penulis dan teman sejawat bekerjasama dengan Ibu Siti Nurrohmawati, S.Pd.SD. guru kelas V sebagai pengamat. Penulis mengadakan pembelajaran Matematika dengan menggunakan media bungkus batang korek api. Selama proses pembelajaran berlangsung teman sejawat mengamati dan mencatat penelitian sebagai pengajar. Hasil pengamatan dalam siklus pertama pertemuan 1 sebagai berikut :

1) Hasil tes formatif menunjukan nilai rata-rata 72,5 .

2) Hanya 6 siswa yang nilainya diatas KKM.

3) Masih 10 siswa yang belum tuntas.

Jadi hasil belajar nilai pada pembelajaran siklus 1 pertemuan 1 ada sedikit peningkatan dari rata-rata awal 68 menjadi 72,5.

Tabel 1 . Hasil Tes Siswa Pada Siklus 1 pertemuan 1 Siklus I Pertemuan 1 Hari Sabtu, 5 Maret 2018

\begin{tabular}{|c|l|c|c|}
\hline NO & \multicolumn{1}{|c|}{ NAMA } & Nilai & Keterangan \\
\hline 1 & Cempaka Sri Saputri & 80 & T \\
\hline 2 & Fadhil Muhammad Ilham & 70 & BT \\
\hline 3 & M. Taufiq Agung Purnomo & 65 & BT \\
\hline 4 & Ayinda Putri Septiana & 80 & T \\
\hline 5 & Tania Az-zahra & 80 & T \\
\hline
\end{tabular}




\begin{tabular}{|c|l|c|c|}
\hline 6 & Erin Tri Noviani & 70 & BT \\
\hline 7 & Arkana Ilham Naufal & 90 & T \\
\hline 8 & Jesseca Auryn Rumekso & 80 & T \\
\hline 9 & Michael Handy Kendrano & 75 & T \\
\hline 10 & Michael Ivander Narda & 65 & BT \\
\hline 11 & Andrean Kristiya & 65 & BT \\
\hline 12 & Aprilia Salasa Setia Putri & 70 & BT \\
\hline 13 & Keisha Arka Puspita & 70 & BT \\
\hline 14 & Salsabila IlIona Maharani & 65 & BT \\
\hline 15 & Vinsencius Junior Rafael Armanto & 65 & BT \\
\hline 16 & Elisabet Karisma Widyawati & 70 & BT \\
\hline & Jumlah Nilai & 1160 & \\
\hline & Rata - rata & 72,5 & \\
\hline & KKM & 75 & \\
\hline & & & \\
\hline
\end{tabular}

Ketrrangan :

$\mathrm{T}=$ Tuntas

BT $=$ Belum Tuntas

\section{Siklus 1 pertemuan 2}

Berdasarkan hasil pengamatan guru, selama proses pembelajaran matematika pada siklus 1 pertemuan 2 di peroleh data :

1) Hasil tes formatif pada pembelajaran siklus 1 Pertemuan 2 menunjukkan rata-rata 74,06.

2) Siswa sudah tertarik pembelajaran.

Berdasarkan data di atas hasil belajar pada siklus kedua ini ada peningkatan dari nilai rata-rata 72,5 menjadi 74,06. Jadi hasil belajar siklus 1 pertemuan ke 2 ada peningkatan dari rata-rata 72,5 menjadi 74,06.

Tabel 2 . Nilai Tes Siswa Pada Siklus 1 pertemuan II Siklus 1 Pertemuan 1 I Hari Rabu, 7 Maret 2018

\begin{tabular}{|c|l|c|c|}
\hline NO & \multicolumn{1}{|c|}{ NAMA } & Nilai & Keterangan \\
\hline 1 & Cempaka Sri Saputri & 90 & $\mathrm{~T}$ \\
\hline 2 & Fadhil Muhammad Ilham & 70 & BT \\
\hline 3 & M. Taufiq Agung Purnomo & 75 & $\mathrm{~T}$ \\
\hline 4 & Ayinda Putri Septiana & 80 & $\mathrm{~T}$ \\
\hline 5 & Tania Az-zahra & 80 & $\mathrm{~T}$ \\
\hline 6 & Erin Tri Noviani & 75 & $\mathrm{~T}$ \\
\hline 7 & Arkana Ilham Naufal & 100 & $\mathrm{~T}$ \\
\hline 8 & Jesseca Auryn Rumekso & 80 & $\mathrm{~T}$ \\
\hline 9 & Michael Handy Kendrano & 75 & $\mathrm{~T}$ \\
\hline 10 & Michael Ivander Narda & 65 & $\mathrm{BT}$ \\
\hline 11 & Andrean Kristiya & 70 & $\mathrm{BT}$ \\
\hline 12 & Aprilia Salasa Setia Putri & 75 & $\mathrm{~T}$ \\
\hline 13 & Keisha Arka Puspita & 75 & $\mathrm{~T}$ \\
\hline 14 & Salsabila IlIona Maharani & 55 & $\mathrm{BT}$ \\
\hline 15 & Vinsencius Junior Rafael Armanto & 60 & $\mathrm{BT}$ \\
\hline 16 & Elisabet Karisma Widyawati & 60 & $\mathrm{BT}$ \\
\hline & Jumlah Nilai & 1185 & \\
\hline
\end{tabular}




\begin{tabular}{|l|l|c|l|}
\hline & Rata - rata & 74,06 & \\
\hline & KKM & 75 & \\
\hline
\end{tabular}

\section{Siklus 2 Pertemuan I}

Selama proses pembelajaran berlangsung teman sejawat mengamati dan mencatat penelitian sebagai pengajar. Hasil pengamatan dalam siklus II pertemuan I sebagai berikut :

1) Hasil tes formatif menunjukan nilai rata-rata $78,12$.

2) Hanya 11 siswa yang nilainya diatas KKM.

3) Masih 5 siswa yang belum tuntas.

4) Siklus 2 Pertemuan I

Tabel 3.Hasil Tes Siklus II Pertemuan I Siklus II Pertemuan I Hari Sabtu, 10 Maret 2018

\begin{tabular}{|c|l|r|c|}
\hline NO & \multicolumn{1}{|c|}{ NAMA } & Nilai & Keterangan \\
\hline 1 & Cempaka Sri Saputri & 85 & $\mathrm{~T}$ \\
\hline 2 & Fadhil Muhammad Ilham & 75 & $\mathrm{~T}$ \\
\hline 3 & M. Taufiq Agung Purnomo & 65 & $\mathrm{BT}$ \\
\hline 4 & Ayinda Putri Septiana & 80 & $\mathrm{~T}$ \\
\hline 5 & Tania Az-zahra & 85 & $\mathrm{~T}$ \\
\hline 6 & Erin Tri Noviani & 75 & $\mathrm{~T}$ \\
\hline 7 & Arkana Ilham Naufal & 90 & $\mathrm{~T}$ \\
\hline 8 & Jesseca Auryn Rumekso & 80 & $\mathrm{~T}$ \\
\hline 9 & Michael Handy Kendrano & 75 & $\mathrm{~T}$ \\
\hline 10 & Michael Ivander Narda & 70 & $\mathrm{BT}$ \\
\hline 11 & Andrean Kristiya & 70 & $\mathrm{BT}$ \\
\hline 12 & Aprilia Salasa Setia Putri & 75 & $\mathrm{~T}$ \\
\hline 13 & Keisha Arka Puspita & 80 & $\mathrm{~T}$ \\
\hline 14 & Salsabila IlIona Maharani & 60 & $\mathrm{BT}$ \\
\hline 15 & Vinsencius Junior Rafael Armanto & 55 & $\mathrm{BT}$ \\
\hline 16 & Elisabet Karisma Widyawati & 75 & $\mathrm{~T}$ \\
\hline & Jumlah Nilai & 1195 & \\
\hline & Rata - rata & 74,68 & \\
\hline & KKM & 75 & \\
\hline
\end{tabular}

\section{Siklus 2 Pertemuan 2}

Selama proses pembelajaran berlangsung teman sejawat mengamati dan mencatat penelitian sebagai pengajar. Hasil pengamatan dalam siklus 2 pertemuan 1 sebagai berikut :

1) Hasil tes formatif menunjukan nilai rata-rata 82,81

2) Terdapat 15 siswa yang nilainya diatas KKM.

3) Masih 1 siswa yang belum tuntas.

4) Suasana pembelajaran menjadi menyenangkan.

Hasil evaluasi terjadi kenaikan rata-rata kelas pada pembelajaran yaitu dari 74,68 menjadi 82,81 
Tabel 4. Hasil Tes Siklus II Pertemuan II Siklus II pertemuan II Hari Senin, 12 Maret 2018

\begin{tabular}{|c|l|l|c|}
\hline NO & \multicolumn{1}{|c|}{ NAMA } & Nilai & Keterangan \\
\hline 1 & Cempaka Sri Saputri & 100 & $\mathrm{~T}$ \\
\hline 2 & $\begin{array}{l}\text { Fadhil Muhammad } \\
\text { Ilham }\end{array}$ & 80 & $\mathrm{~T}$ \\
\hline 3 & $\begin{array}{l}\text { M. Taufiq Agung } \\
\text { Purnomo }\end{array}$ & 75 & $\mathrm{~T}$ \\
\hline 4 & Ayinda Putri Septiana & 100 & $\mathrm{~T}$ \\
\hline 5 & Tania Az-zahra & 100 & $\mathrm{~T}$ \\
\hline 6 & Erin Tri Noviani & 75 & $\mathrm{~T}$ \\
\hline 7 & Arkana Ilham Naufal & 100 & $\mathrm{~T}$ \\
\hline 8 & Jesseca Auryn Rumekso & 85 & $\mathrm{~T}$ \\
\hline 9 & $\begin{array}{l}\text { Michael Handy } \\
\text { Kendrano }\end{array}$ & 80 & $\mathrm{~T}$ \\
\hline 10 & Michael Ivander Narda & 80 & $\mathrm{~T}$ \\
\hline 11 & Andrean Kristiya & 75 & $\mathrm{~T}$ \\
\hline 12 & $\begin{array}{l}\text { Aprilia Salasa Setia } \\
\text { Putri }\end{array}$ & 75 & $\mathrm{~T}$ \\
\hline 13 & Keisha Arka Puspita & 85 & $\mathrm{~T}$ \\
\hline 14 & $\begin{array}{l}\text { Salsabila IlIona } \\
\text { Maharani }\end{array}$ & 75 & $\mathrm{~T}$ \\
\hline 15 & $\begin{array}{l}\text { Vinsencius Junior } \\
\text { Rafael Armanto }\end{array}$ & 60 & $\mathrm{BT}$ \\
\hline 16 & $\begin{array}{l}\text { Wlisabet Karisma } \\
\text { Widyawati }\end{array}$ & 80 & $\mathrm{~T}$ \\
\hline & Jumlah Nilai & 1325 & \\
\hline & Kata - rata & 75,81 & \\
\hline
\end{tabular}

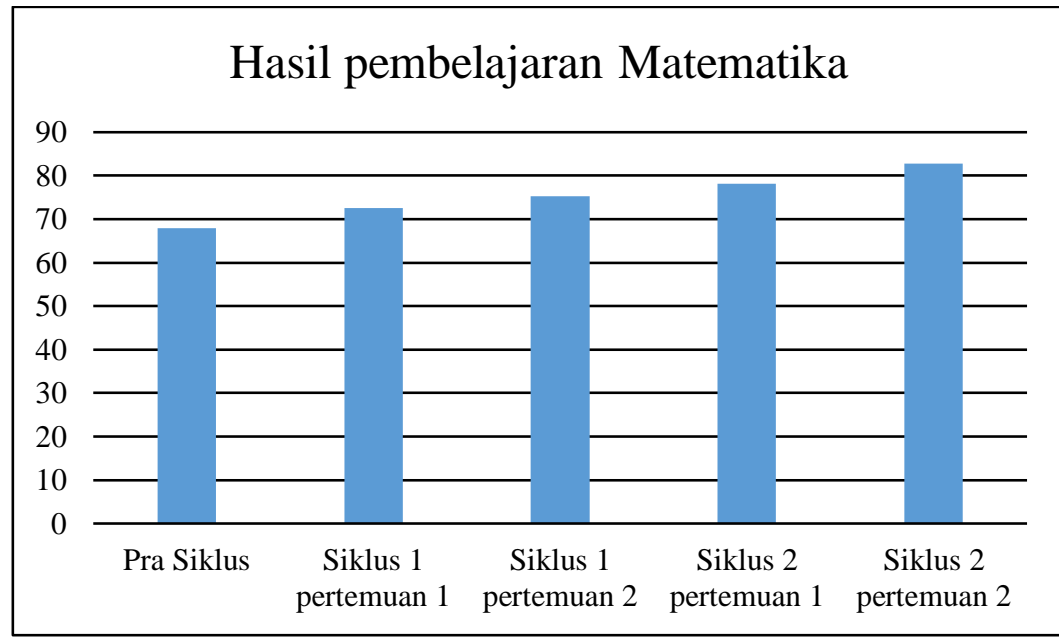

Tabel 5. Grafik Hasil Tes Pembelajaran Matematika 


\section{Pembahasan}

Kondisi yang melatar belakangi penelitian ini adalah siswa tidak bersemangat, nilai ulangan harian matematika masih rendah di Tahun Ajaran 2017/2018, belum memenuhi KKM yang di terapkan yaitu 75. Sesuai dengan pendapat penjelasan Smaldino, et.al (2011) media diartikan sebagai segala sesuatu yang merujuk pada penyampaian informasi dan pesan antara sebuah sumber dan sebuah penerima sebagai wujud dari sarana komunikasi. Dengan demikian penelitian tindakan kelas akan memperbaiki kondisi tersebut. Dengan penggunaan media bungkus batang korek api tersebut dapat meningkatkan hasil belajar siswa meningkat.

Hasil dari siklus 1sampai dengan siklus 2 terlihat adanya peningkatan.Dengan adanya media bungkus batang korek api, nilai rata-rata pada pra siklus 68,meningkat ke siklus 1 pertemuan 1menjadi 72,5 dan pada siklus 1 pertemuan 2 mengalami peningkatan menjadi 74,06, pada siklus 2 pertemuan 1 mengalami peningkatan menjadi 74,68 dan pada siklus 2 pertemuan 2 ketuntasan KKM mengalami peningkatan menjadi 82,81. Dari hasil tindakan siklus 1 sampai siklus 2 ini terlihat media bungkus batang korek api merupakan salah satu alternatif media yang bisa di terapkan dalam pembelajaran matematika.

\section{DAFTAR PUSTAKA}

Arikunto, Suharsimi. (2015). Penelitian Tindakan Kelas Edisi Revisi. Jakarta : Bumi Aksara. Karso, dkk. (2008). Pendidikan Matematika 1 . Cetakan 6 Jakarta : Universitas Terbuka. Nyimas Aisyah,dkk. (2007). Pengembangan Pembelajaran Matematika SD. Jakarta : Direktorat Jenderal Pendidikan Tinggi Departemen Pendidikan Nasional.

Soli Abimanyu, dkk. (2009). Strategi Pembelajaran. Jakarta : Direktorat Jenderal Pendidikan Tinggi Departemen Pendidikan Nasional.

Sungkono, dkk. (2008). Pengembangan Bahan Pembelajaran SD . Jakarta : Universitas Terbuka

Tim Penyusun Pusat Bahasa (Mendikbud). (2007). Kamus Besar Bahasa Indonesia. Jakarta: Balai Pustaka.

https://heminegari.wordress.com.diakses pada tanggal 21 Oktober 2015 pukul : 05.00.

Friska Dwi Yusantika1, Imam Suyitno2, Furaidah. (2018). Pengaruh Media Audio dan Audio Visual terhadap Kemampuan Menyimak Siswa Kelas IV. Jurnal Pendidikan, Volume: 3 Nomor: 2 